\title{
LIBERDADE E AUTONOMIA NA RELAÇÃO PEDAGÓGICA E PSICANALÍTICA: UMA APROXIMAÇÃO DA PEDAGOGIA DA LIBERTAÇÃO FREIREANA COM A PSICANÁLISE LACANIANA
}

\begin{abstract}
Ananda Figueiredo Rocha Mestranda em Educação, Universidade do Extremo Sul Catarinense, anandafigr@hotmail.com
\end{abstract}

\section{RESUMO}

Este ensaio propóe-se a refletir acerca das relaçóes que constituem a conscientizaçáo de Freire e o sujeito de suposto saber de Lacan, compreendendo que ocorrem em espaços e com finalidades diferentes, mas se assemelham especialmente no que se refere à libertação do sujeito de alguém/algo que o oprime - incluindo aqui a auto-opressão -, em um processo autônomo de desenvolvimento. É importante esclarecer, contudo, que este trabalho não tem como objetivo expor a integralidade da teoria psicanalítica, tampouco da freireana, o que resulta em uma superficialidade conceitual certamente não desejável, mas inevitável, dada às atuais limitaçóes da pesquisadora. Jacques Lacan (1901-1981) foi um psicanalista francês que construiu sua teoria a partir da retomada do Cogito Ergo Sum de Descartes, afirmando que, deste modo, há uma subordinação do ser ao pensamento. Para ele, a máxima viável em toda psicanálise é "ou eu não penso, ou eu não sou" e, a partir dela, desenvolveu a ideia de "sujeito suposto saber" (SsS), aspecto fundamentado no inconsciente - onde não há pensamento 
racional -, que se refere à capacidade de atribuir, neste caso, ao outro a condição de conhecedor de algo que o indivíduo desconhece. Por meio deste processo, inicia-se a transferência na relação analítica, o que garante seu sucesso (LACAN, 2001). Em outras palavras, se inicialmente o paciente náo crer que o psicanalista conhece maneiras por ele desconhecidas de resolver seu problema, o processo não avançará. Há neste momento, portanto, uma hierarquização de saberes: o problema do sujeito, crê ele, só poderá ser resolvido pelo analista. Em um olhar superficial, não seria possível afirmar similaridade com o entendimento de Paulo Freire (1921-1997) acerca das relaçóes, especialmente a pedagógica. Para o educador brasileiro, esta é pautada no diálogo com o outro, entendido como aquele que possui outros saberes, mas não menos importantes para processo: "não há saber mais, nem saber menos, há saberes diferentes" (FREIRE, 1987, p. 68). Na relação pedagógica, portanto, o professor - ou coordenador - não ocupa papel central. Ele é parte de uma relação dual que propicia a descoberta e a conscientização autônoma do sujeito de sua condição ontológica, que lhe permite compreender que é parte do mundo e, assim, autor de sua história. A conscientização resulta, então, no fim da condição de oprimido e no exercício da autonomia. Pode-se afirmar que o sujeito de suposto saber na relação transferencial se caracteriza pela dependência emocional do paciente, que, por se subordinar a consciência do psicanalista, ocupa aqui posição de oprimido. Neste sentido, seria a relação analítica uma relação opressora, impedindo a libertação do indivíduo? Para Lacan, o SsS é a posição de partida necessária para a prática psicanalítica. No entanto, avançando no processo, ocorre a passagem desta condição para a posição de desser, tendo como ponto de chegada o momento no qual o paciente reconhece que o saber que se procura na análise é dele próprio, o que enfraquece o SsS, a ponto de inexistir no processo. Logo, é preciso que o psicanalista permita que esta suposiçáo de saber se mantenha por algum tempo, mas que depois possa cair para que o saber inconsciente, que é constitutivo do sujeito, venha à luz. Este processo se dá dialeticamente, na situação relacional em que psicanalista e paciente se encontram. Aqui, tem-se um ponto importante de aproximação: em ambas as relaçóes, a chegada ao saber se dá com a participação de um mediador, seja ele o professor ou o psicanalista. O papel deles é possibilitar maneiras para 
que o aluno ou o paciente tome consciência e decida criticamente, de modo autônomo, como solver suas dificuldades e agir sobre sua vida. Tanto o professor de Freire quanto o psicanalista de Lacan, ainda que atuem como mediadores e náo como determinantes na relação dual, não são neutros neste processo. Enquanto Lacan explana sobre o "desejo do analista", referindo-se ao fato de que este é alguém desejoso na e para a sua relação com o paciente, Freire admite que, antes de professor, é sujeito que possui um compromisso social com a mudança. Toda mudança interior resulta em outra exterior. Lacan, preocupado inicialmente com o desenvolvimento subjetivo do sujeito, e Freire, que se comprometeu com a transformação do sujeito, a fim de revolucionar uma sociedade, ainda que em áreas distintas, buscavam possibilitar o desenvolvimento do ser para a vivência de sua vocação ontológica de homem, da qual se concorda com Freire: "ser mais". A libertação de Freire, concretizada na conscientização, é um processo subjetivo, individual, mas também histórico-social, que busca o conhecimento da situação do sujeito e sua análise crítica, resultando no rompimento da opressão. A libertação psicanalítica, sustentada aqui por Lacan, ainda que também subjetiva, visa ao aprofundamento do sujeito em sua construção inconsciente que, desconhecida, também o oprime. Em ambos os casos, observou-se a necessidade de um saber autônomo para o rompimento de uma situação alienante que, conhecida, causa sofrimento (FREIRE, 1979).

Palavras-chave: Psicanálise; Educação; Liberdade; Autonomia.

\section{INSTITUIÇÃO FINANCIADORA}

Programa de Bolsas Universitárias de Santa Catarina - UNIEDU.

\section{REFERÊNCIAS}

FREIRE, P. Conscientização: teoria e prática da libertação: uma introdução ao pensamento de Paulo Freire. Sáo Paulo: Cortez e Moraes, 1979. 
. Pedagogia do oprimido. 17. ed. Rio de Janeiro: Paz e Terra, 1987.

LACAN, J. O ato psicanalítico. Porto Alegre: Escola de Estudos Psicanalíticos, 2001. 